history (7). Indeed, the graphic format has much to offer activists today. In Hill's words: "The strength of the comic book is that it uses minimal text with graphic art to tell the story. This format is useful for reaching children, youth, and adults who have a hard time reading books or lengthy articles. We may use many diverse methods of communication-including newsletters, books, videos, music, posters, stickers, paintings, banners, and T-shirts-because no simple one will be successful by itself" (6). There are, of course, limitations to the graphic medium and to Hill's work specifically. For example, Hill chooses to exclude the important political movements fighting for land and dignity through legal channels. One reason for this choice could be that the logistics of legal battles do not lend themselves as easily to the graphic artist as do the events of blockades and occupations. Nevertheless, Hill's work could have also discussed such tactics and strategies to render a more nuanced picture of ongoing indigenous resistance to colonialism.

The 500 Years of Resistance Comic Book is both an important contribution to the literature on colonialism in the Americas and a major intervention in the emerging field of activist graphic history. In our struggles to renew activist energy for the twenty-first century, we must embrace graphic histories, like Hill's comic book, as significant tools that can help inspire people's critical engagement with the past and present.

Sean Carleton

Trent University

\title{
Ian Hesketh, The Science of History in Victorian Britain (London: Pickering \& Chatto, 2011).
}

This is a book about how Victorians wrote history and the struggle within the discipline in determining history's appropriate subject matter, methodology, and boundaries. Intellectual historian Ian Hesketh uncovers a surprisingly complex conflict in the professionalisation of history. He does this by presenting material gleaned from diverse sources including public lectures and obituaries. At the heart of this conflict is the question of whether history is an art or a science. Through extensive research, the author reveals a much more multifaceted struggle than traditionally perceived in a somewhat aggressive pursuit to make history a science.

In this detailed analysis, Hesketh depicts an ongoing battle to establish the proper domain and method of history through the examination of the lectures and letters of renowned historians. Henry Thomas Buckle is presented as a champion of the scientific method with a soft side for the artistic component. The more hardcore proponents of an inductive method of science include 
William Stubbs, Lord Acton, J. R. Seeley and Edward A. Freeman. Despite a foreign influence on these last, through the work of German scientific historian Leopold von Ranke, Hesketh is quick to identify parallels between this German method and a very English tradition of Baconian induction, making such a model more amenable to Victorian sensibilities. Finally, at the opposite end of the spectrum, we meet those supporting an artistic, "great men" approach to history, namely Charles Kingsley and James Anthony Froude. One of the book's strengths lies in its exposure of the diverse routes taken by these historians in pursuing the establishment of a science of history. As Hesketh reveals, this struggle was a messy business with little consensus as to what kind of science history should be, what method it should undertake, and what identity was required by historians in carrying this out.

With the battleground set, the most interesting part of the book commences: the fight itself, or rather, the attempt by the Rankean adherents to exclude their opponents. This examination of boundary making within the discipline of history presents a cut-throat academic milieu in which scientific historians attacked their adversaries through scathing criticism in lectures, letters, and reviews. They further demarcated their field as a professional and scientific one, by establishing their own journal, the English Historical Review. Yet, as Hesketh reveals, students of history and the discipline's general readership were not prepared to turn their backs on a traditional artistic history, as the appeal of a good story proved stronger than strict adherence to laying out the facts.

By comparing the professionalisation of history with that of science, this seemingly specialised study is presented as part of a greater struggle for cultural authority. The Rankeans were motivated by the same ideology as the scientific naturalists were in their attempts to demarcate their discipline and rid it of the perceived fluff that degraded their work. Underpinning this larger context, Hesketh unravels further ideological conflicts by examining how these scientific historians were influenced in their campaigns by philosophical and religious agendas. Of particular interest is Hesketh's assertion that, in the search for objectivity, Rankean scientists sought to create a new and separate self, free of bias and subjectivity, in proclaiming their judgments on the historical record. This creation of a separate self, or at least a different identity, occurs again in the case of certain historians, who, in acknowledging the public's desire for a good story, would write in one fashion for such an audience and in another for their peers.

The hostilities dissipated by the beginning of the twentieth century, with a general acceptance that poetic imagination and primary sources both had places in the writing of history. While Hesketh makes no direct reference to any influence from the new sciences of the mind which were emerging at the same time, it is interesting to speculate that the accommodation of subjectivity within these new branches of science made it easier for a form of history to emerge 
that would not only tolerate, but encourage both the subjective and the objective. In writing this history, a history of the conflict over how history should be written, Hesketh's own method is inevitably scrutinized and compared to those of whom he writes. He recognizes this and claims to intentionally employ a "subtle" form of analysis through description, so that readers might find their own path. As such, his approach encompasses both the technique of the Rankeans, in its dependence upon archival sources and the historical record, and that of the historians who championed a "great men" method of history, with reliance on biographical detail.

This is a book concerned with parallels. Hesketh compares historians with leading scientists of the era; he compares historical method with scientific method and also with philosophical method. This is all part of his subtle analysis to let readers find their own way. But perhaps it prevents a way - does description and comparison without inference point in any obvious objective direction? If not, perhaps this is the author's purpose.

Regardless, this colorful and conflicted history of the battle between the art of history and the science of history is a welcome addition to the growing literature on nineteenth-century science and culture. Hesketh's contribution is of interest not only to Victorian scholars and intellectual historians, but to historians of all stripes in demonstrating the concerns of our predecessors in establishing the boundaries of our discipline, concerns that are still of relevance today.

Alison Butler Memorial University of Newfoundland

Kristin Burnett, Taking Medicine: Women's Healing Work and Colonial Contact in Southern Alberta, 1880-1930 (Vancouver: UBC Press, 2010).

In Taking Medicine: Women's Healing Work and Colonial Contact in Southern Alberta, 1880-1930, Kristin Burnett considers the subverted roles of Aboriginal and settler women in domestic and increasingly institutionalized healing and nursing practices in the Treaty 7 contact zone. Noting "patterns of persistence, resistance, and change" in Aboriginal women's curative and caregiving work throughout these decades, Burnett argues that Aboriginal and settler women's vital therapeutic work in the late nineteenth and early twentieth centuries was displaced with the expansion of white settlement and that it struggled to persist through the Department of Indian Affairs' (DIA) internal colonial policies (4,14). By examining the convergence of colonialism, liberalism, positivism, and gender, Burnett sets out to challenge the predominance of the "medicine man" in historical documents and in traditional understandings of Aboriginal and settler healing practices. 